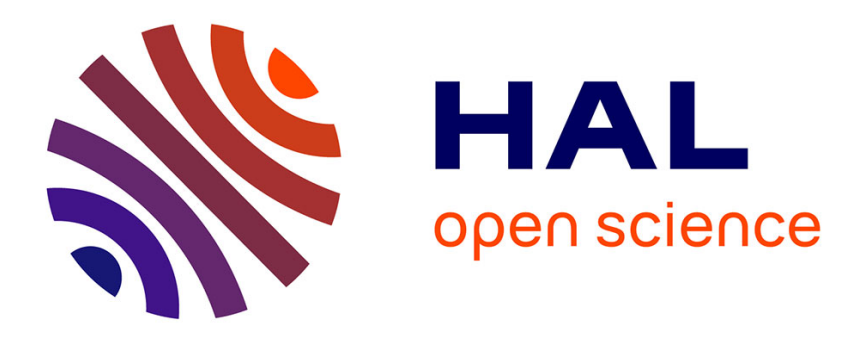

\title{
Implicit large territorial-technical system: settlement systems
}

Denise Pumain

\section{To cite this version:}

Denise Pumain. Implicit large territorial-technical system: settlement systems. Flux - Cahiers scientifiques internationaux Réseaux et territoires, 1995, 21, pp.11-20. halshs-01625377

\section{HAL Id: halshs-01625377 https://shs.hal.science/halshs-01625377}

Submitted on 27 Oct 2017

HAL is a multi-disciplinary open access archive for the deposit and dissemination of scientific research documents, whether they are published or not. The documents may come from teaching and research institutions in France or abroad, or from public or private research centers.
L'archive ouverte pluridisciplinaire HAL, est destinée au dépôt et à la diffusion de documents scientifiques de niveau recherche, publiés ou non, émanant des établissements d'enseignement et de recherche français ou étrangers, des laboratoires publics ou privés. 
of dependence,

public confider

and constancy
Dominique LORRAINE

The regulation of

urban technical

networks

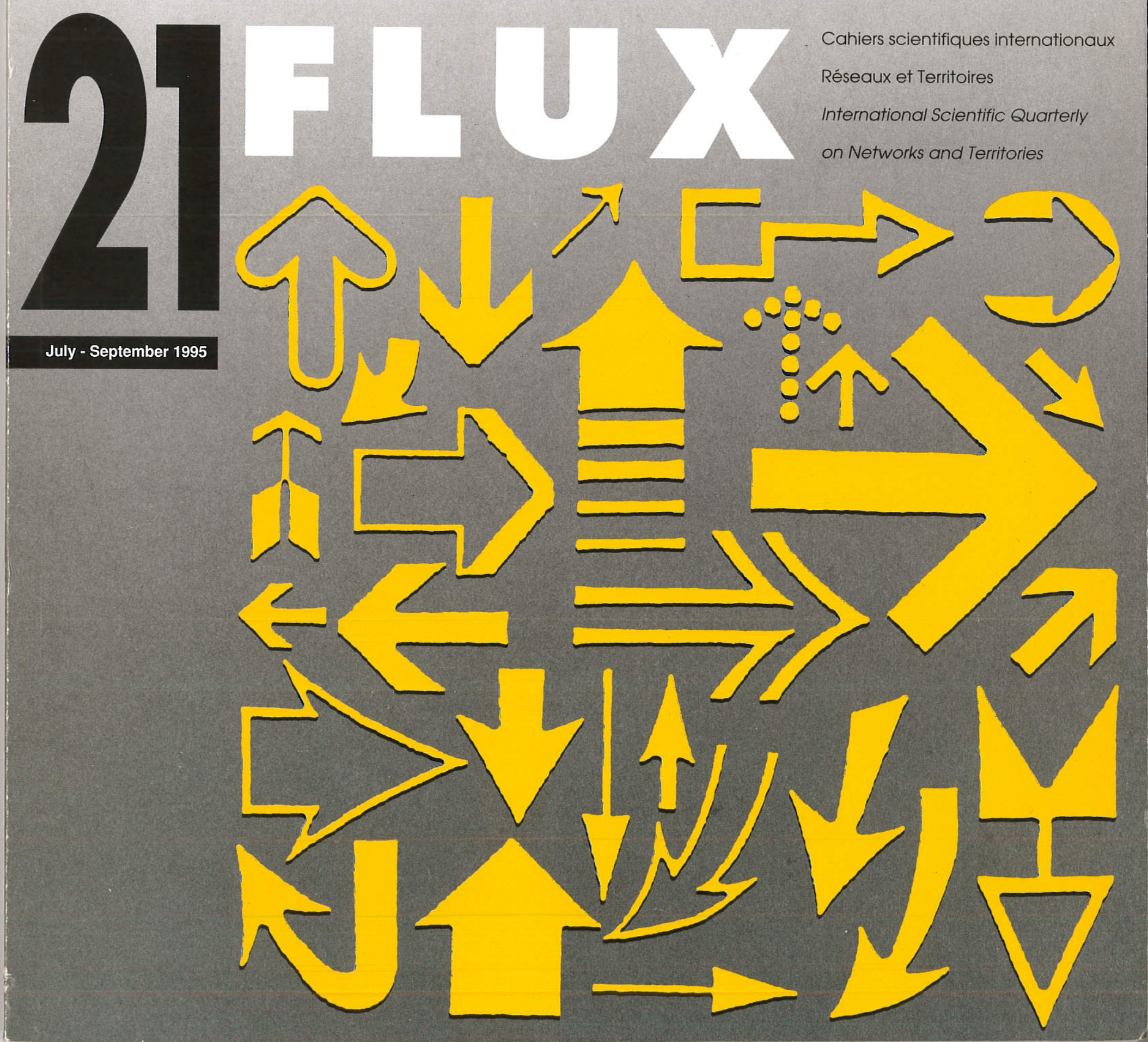


FLUX

$n^{\circ} 21$ July - September

pp. $11-20$ large territorial-technical

system:

settlement systems
A paraître

dans Flux 22, Octobre - Décembre 1995, en français

Renate MAYNTZ

Progrès technique, changement social et développement

de grands systèmes techniques

(Technical progress, societal change, and the development of large technical systems)

Gene I. ROCHLIN

Pris dans la toile: réseaux globaux, mutation des systèmes et

comportements conformes à l'ère de l'information

(Trapped by the web: Networking, transformation and compliance in the computer age

Stephen SALSBURY

Les grands systèmes techniques : problèmes liés à la traversée des

frontières politiques et géographiques

(LTS: Patterns of development over time the example of railroads and electric power)

Comptes rendus des tables rondes:

1) Usagers, contribuables, citoyens

2) Le service universel et l'équité territoriale : jusqu'où ?

(Round table discussions: 1) Users, taxpayers, citizens 2) Universal service and territorial equity: How universal and how equitable?

In the next issue of Flux No. 22, October - December 199
Denise PUMAIN, who studied at the Ecole Normale Superieure of Fontenay-aux-Roses, holds the doctorate in social sciences and letter She is Professor at the University of Paris-I and associated researcher he Institut National d'Etudes C.N.R.S. research group “P.A.R.L.S.E.H.G.O." (URA I243) Her work deals with theoretical cities, and the modelization of the dynamics of systems of cities. She is the author of La dynamique des villes (1982), and co-author of the Atlas des oilles de France (198), , Filince
organisation (1989), La France Géographie Universelle RECLUS, 1990), the Encyclopedie de Geograp (1992 and 1591$)$ syde de ves villes europeennes (1994) and Espace des
Villes (1995). She is in charge of the collection "Villes" for Anthropos Publishers.
DENISE PUMAIN

Several theorists, such as P. Vendryes, provide a very general interpre$S_{\text {tation of the finality (conscious or unconscious) of the great technical }}^{\text {EVRAL }}$ innovations undertaken through the course of history by human societies. The underlying trend behind these achievements is an attempt to reduce the uncertainties which threaten these societies' ability to maintain and reproduce. To a large extent, the risks to which societies are subjected come from their dependence on the unforseeable variations of their immediate environment, on the fluctuations in the resources offered by the close territory, the site on which they are established. A considerable amount of energy is therefore spent by most societies to ensure control over distant sites, over a wider territory, and to develop communication between complementary resources provided by different sites (Reymond, 1981)

The concept of a large technical system is used to designate conscious ttempts to control this process of creating communication links (Bijker, Hughes, Pinch, 1987). We wish to explore here the similarities between their functioning and that of a system which, although it is insufficiently or not consciously controlled, has none the less proved to be exceptionally efficient for the running and management of territories and especially for the lasting development of societies. We are referring to what is known as the settlement system, whose function is to link the territories of daily life to territories with a wider reach and which, by linking up the resources of increasingly distant sites, make it possible to go beyond the ecological limits to the development of human settlements. The setlennent systent thus appears as the major adaptation instrument of social organizations to the conditions offered by the surface of the earth, according to a process which tends to replace surface area and the natural environment by space produced by human societies.

\section{THE CONCEPT OF THE SETTLEMENT SYSTEM}

A settlement system is defined, in a given territory, by all of the inhabited nodes, hamlets, villages, towns and the communication networks, equipment and information that connect these nodes. The notion of territory is taken here in its administrative or political sense, as a contiguous portion of the earth's surface appropriated by a group, which signifies a degree of homogeneity of the socioeconomic conditions and overall control over possible circulation in the territory (Hubert 1993). Networks are engendered by and enable multiple 
interactions between the inhabitants of the various settlement nodes, whether these be monetary (trade), human (migration) or informational. The environment of this system, initially and above all constituted by the agriculsystem, initially and above all constituted by the agricu-
tural and mining resources of the accessible territory, has, through history, become less and less limited by the has, through history, become less and less limited by the trial and urban society has developed and has gradually become its own milieu.

The world's settlement systems are characterized by very strong properties, relatively invariable depending on the historical period or territory being considered The first property is a very hierarchical structure, which translates into great differenciation of the size of the elements in the system, from a few dozen inhabitants in hamlets to more than $10^{6}$ in today's large metropolita areas. The general model which demonstrates this organization is an inverse geometric progession of the number of towns according to their size. Historical studies (De Vries, 1984 ; Carroll, 1992), or even archaeological studies (Fletscher, 1986), as well as the most recent international comparisons (Moriconi, 1993), all bear witness to the universality of this model in space and time.

This hierarchical structure is accompanied by a certain regularity in the spacing of the population units, generally even greater where large towns are concerned The theory of central places (Reynaud, 1841, quoted by Robic, 1982; and Christaller, 1933), explains this configuration by the principle of centrality, which justifies the grouping in the same place of the production of services of the same level destined for a dispersed population in a complementary area (or zone of influence), whose center polarizes the clientele. The centers are hierarchical due to the existence of several levels of sevices defined by spatial range (the distance that the customer accepts to travel to obtain the service) and by appearance thresholds (determined by the volume of customers necessary for the profitability of the service offered). The zones of influence of the centers are superimposed as upper level centers generally offer all services of lesser reach. Competition between centers consequently leads to regularity in the spacing (dis tancing) of towns, and the hierarchy in the levels of services leads to a lesser number and greater spacing of centers as one moves up in the hierarchy.

The second very general property, not taken into account by the theory of central places, is a functiona differenciation of the inhabited sites which, for sites of equal size, translates into specialization in the various 12 belonging to the same territory. This specialization is sometimes linked to the services offered to the population such as they are taken into consideration by the theory of central places, but they far more frequently result from the concentration of activities whose production is not necessarily destined to a neighbouring clientele. Today, this is the case for most industrial activities, but also for some services, such as transport or business services. If the deposits in the mining basin or the amenities of tourist areas sometimes determine the grouping of towns specialized in the same type of activities, the localization of specialized towns is most often very sporadic and follows no regular pattern. Specialization in one or several types of activity defines the complementarity between towns in the same territory and partially conditions their growth. The major specializations emerge along with the greater cycles of technical and economic innovation (for example, that of the first industrial revolution, or of the development of electricity), in particular where they rely on unevenly spread resources (such as coal or ore deposits, or tourist sites). Most often, though, innovations have a dissemination process which conforms to the hierarchical organization of settlement systems (Pred, 1977). Even if innovations may appear anywhere, large towns provide a more favourable milieu for their emergence and, in any case, possess a more diversified social and economic base, from which innovations can be the first to benefit. Innovations are then spread to the rest of the territory, reaching the medium-sized towns, then the small towns, sometimes even the villages. This hierarchical dissemination process helps to maintain and amplify (in view of the initial advantage conferred by the early adoption of an innovation) the hierarchical contrasts in the structure of settlement systems.

The third important property is the very great interdependence of the evoluto the same system. Changes in the morphological configuration (urbanism), in the activities (industrialization or tertiarization), in the social composition (development of salaried employment, increase in qualifications), in the number of inhabitants (rural exodus, urban growth) very rarely appear in an isolated and sporadic manner in a single element of the system. On the contrary, the results of detailed analyses of the change occurring in all the towns of a given territory reveal a great homogeneity and simultaneity of the transformations taking place during a given period (Pumain, Saint-Julien, 1978). As change is of almost the same intensity everywhere, and the inequalities and differences existing at a given time Everyeen towns are maintained over fairly long durations.
Everpens as if, during a given period, towns belonging to the same system undergo a simple translation in the space defined by their socioeconomic characteristics, the settlement system adapting to change without deforming its structure.

This dynamic property leads to a "meta-stability" of the functional and hierarchical structure of the syste over periods which are respectively medium (economic, social or cultural specializations remain very strong for at least a few decades) and long term (inequalities in the size of towns, particularly in the upper part of the hiera chy, generally for several centuries). The resiliance of the structure of the system is the result of its strong connections, provided by exchanges of goods and, above all, by exchanges of information, as well as by competitive attitudes and the imitative behaviour of localize actors, which ensure increasingly rapid dissemination of innovations. The speed with which the system can adapt to change has therefore become far greater than its ow speed of transformation. This trend has become accentuated over historical time with the increase in the speed of communication, which tends to increase the spatia range of interactions within the settlement system an which also has the general consequence of reinforcin its hierarchical structure (Pumain, 1992)

\section{SPECIFIC "TECHNIQUES" FOR} THE TERRITORY

The settlement system holds a key position in what geographers sometimes call the "spatial system" (Pinchemel, 1988 ; Brunet, 1990). This pattern of the articulation of the main social finalities assigned to a territory effectively positions the functions of appropriation, production, circulation and management (administration) in of any society with its territory.

THE FUNCTIONS OF VILLAGES AND TOWNS

While it is obvious that agricultural hamlets and villages are the places that group together the work force that guarantees agricultural production, the multiplicity of functions fulfilled by towns is established as soon as they are set up, and subsequently attested by the fact that is impossible to give towns a simple and unequivocal definition. Thus archaeologists and historians are divid- ed as to the main role of towns, the one that justified (5), With an economic function destined to sell agricultural surplus (Bairoch, 1985), or high places of cult, embodying, in symbolic representations, a religious power (Weatley, 1969 ; Racine, 1993)? Or then again, centers of political power (Duby, 1985)? All towns, right from their origins, have probably
tions to varying degrees.

The difficulty of limiting the notion of a town within a simple definition is another consequence of the diversity of the technical finalities assumed by towns. The first finality is to be a place of residence for a large, permanent group of a population, assembled in a confined area. The demographic, morphological and town planning definitions of a town underline the great dimension and the high density of these settlement agregates, the spatial continuity of "hard" constructions and their organization by town planning rules and technical networks.

The town is also a place of production, since, as it groups together a large population on a limited surface area, it cannot produce sufficient food resources for the survival of its population. The social, functional and economic definitions of the town underline the fact that mainly non-agricultural activities are therein carried out, and that a diversified economic base will develop, thanks to a more or less continuous process of social division of work, technical innovation, and economic specialization. The great urban dimension allows businesses to achieve economies of scale and, above all, urban econonies, hanks to the bringing together of different complementary companies, or even urbanization economies, resulting from the shared use of goods produced by the collectivity, the price of which is not internalized in cost prices, for example, of various public acilies, inftes like the urban heritage or the town's image.

Geographical definitions of the town insist on its territorial role. An urban center carries out central functention for a surre izes relationships. As opposed to villages (or mining sites), which exploit on-site resources from their immediate environment, towns produce situational wealth, enhancing their position in exchange networks, the reach of their action in these networks depending on the size and the specialization of the town (Reymond, 1981). As a result, a town could not be conceived in isolation. It is lways part of a network of towns; it is an element in a settlement system. 
The settlement system plays an obvious role in the networking of the various activities performed in each of he population nodes. With regard to the territory, it thu funts a major function of control and connection. This function is expressed by such metaphors as "urba ant the var", which evokes the task of holding together (yily the an analogy can be drawn between hydrographic networks and their very hierarchical and rat, "irrigate" all parts of a teritory. Not oly the "drain" "irrigate "all parts of a teritory. Not only the towns, the fure

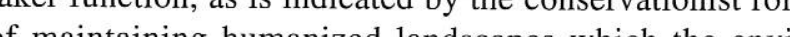

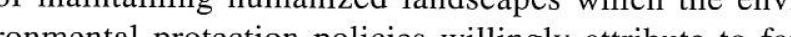

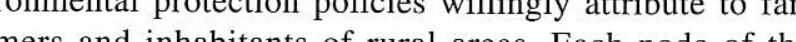
ettlement system is an entity, increasing in code of the from the village through to the metropolis, but whose existence and evolution can only be underst but whose their belonging to that higher level entity that comprises the settlement system of a territory. If one linits onises to interpreting the finalities fulfilled by a settle onese tem from the point of view of management and territorial development techniques, it is possible to put forward wo conceptions, one static and the other dynarc, of the main functions of this system.

\section{FROM THE TERRITORY OF DAILY LIFE TO} THE TERRITORY OF POWER

The static point of view consists in underlining the role of the population system, at a given moment, within the articulation of the territorial entities on different geographic scales, in relating levels of territorial organization which do not have the same space-time dimensions. The population system thus makes it possible to manage the coexistence of at least two main levels.

The first is the territory that is frequented daily, represented by a town and its immediate environment (including the peri-urban residences of people commuting to their place of work, the catchment area of urba commerce, that can be grouped together under the heading "life basin"). The term territory here takes on connotation that is less political and admistrative, an more psychological and sociological, as most town have lost, during the course of history, the ability to decree legal rules or exercise political power, which are today the prerogative of states. We still speak of territory because the community inhabiting the same node of population generally still owns the legal property of the land and constructions, and also defines itself by various feelings of belonging to the place it inhabits. The strong value given to the central zone, and its compactness - it has the best accessibility and groups together a large proportion of the production function, particularly the most elaborate, modern forms, rejecting part of the residential function outwards to the periphery - is the main characteristic of the organization of these territories of daily life, and all the more so if they are large territories. This characteristic is also expressed in the very widespread peripery, the periphelient between the center and the periphery, the peripheral dilution of the intensity of builresulting from thes the fractality of this urban structure, resulting from the compromise between the force of the constraint linked to the advantages of centrality and the necessary "need for spacing" (two constructions cannot which is the seconday v " Rey "nhich is the secondary valorization of the non built-up, and of its advantages (Frankhiser, 1993).

The spatial extension of this territory of daily life remains very strongly limited by the duration of internal remains very strongly limited by the duration of internal density. Thus it has been observed, for example, that commuting times in France had remained practically

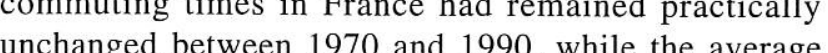
distance travelled had doubled. The average time spent travelling is roughly one hour per day, sometime spent tween one and two hours. Even though this time vary considerably from one individual to the can according to the place, it nonetheless constitutes an invariable in the organization of the territories of daily life, and represents a heavy constraint on maximal spatial extension. The widespread use of automobiles and rapid transport techniques have allowed urban centers to spread to some degree, but the speed of travel within built-up areas is still far slower than that of inter-urban built-up areas is still far slower than that of inter-urban
transport, and the extension of these terriotories of daily life today rarely exceeds a radius of 30 to $40 \mathrm{~km}$ around a center. Much larger urban areas, such as Los Angeles, remain anomalies.

The main functions of this territory of daily life represented by every node of the settlement system are habitat and production (of goods and services). These two major functions, however, are no longer, in most cases, regulated locally. For the most part, what determines their evolution is located elsewhere, in the nodes of the power network where decisions are made. In these networks, some power nodes are clearly identified, by a political or administrative capital, by the head office of a large multinational company, but it is most often through multiple negociation networks, competition or complementarity networks that modalities are determined for collection and exchange of goods, people or information, which guarantee the functioning of the national, or even supra-national.

It is the settlement system that makes these networks function. It is therefore according to the circulation function. It is therefore according to the circulation that the spatial frat of the settla organization that the spatal for of determined, and wich is defined by the size and spacing of the stave one day's travel that determines the distance between the degree of decision meking power (see, for exente ning of the nineteenth centhry, the region capits even today's get Eunopen, me daily temporality (always an estimation, difficult to determine accurately), accepted on average for relatively frequent negociations, determines a far greater possibility of spatial extension for the territories of power than ity of spatial extension for the territories of power than
for the territories of daily life. Indeed, not only the duration which determines the spacing of not only the duration which determines the spacing of nodes in the same territory, but also the speed of travel between the nodes, are generally far greater than those which are possible within each node (Pumain, 1993).

To this remark on space-time duality, one could also add the same form of analysis for settlement systems the temporalities invoked for large technical systems, which generally highlight the existence of two characteristic periods: the long term for installing infrastructures, and the short-term period in which the users are settled.

AN ADAPTOR IN AN EVOLUTIVE SYSTEM

Defining the essential finality of a settlement system in a territory as the articulation of two modes for societies to relate to their environment, each mode having its circulation speed and therefore its specific scale of geographical organization, implies putting this concept into a dynamic rather than a static perspective, and also taking into account the adaptation function of a settlement system, as well as the technical modalities of its achievement. This concept should be put back into an evolutive theory of towns and cities systems (Pumain, 1995).
The necessity for producing an evolutive theory to explain the properties of settlement systems is rooted in common sense, which continues to use the same term for villages and towns, consticts meaning have, however, been totally transformed ove the centuries. This necessity also depends on the aporia ex static theories which are unable to explain, for hierarchical functional levels, or by putting forwing

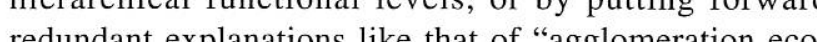
nomies". More than for other social systems, it wo ecoimpossible to explain the similarites in the specific orgaization of population systems, their une specific ture in various geographic milieux, the different economic systems and sociopolitical or mentioning on the one hand, their shared terito finality and without, on the other hand, relating this finality to or proces on thich nonetheless historical, namely urban transition the contraction of space-time. The current structure of settlement systems is the product of these two processes, which have profoundly transformed the practical modalities of their main function and their technical meaning, which remains invariable, and which is the articulatio of territories of daily life and territories of power. It can of territories of daily life and territories of power. It can therefore be considered that the finality of settlement
systems is to reduce local risks by connecting places to systems is to reduce local risks by connecting places to
each other and by achieving continuous adaptation each other and by achieving continuous adaptatio territory.

The current structure of settlement systems represents neither a state of balance nor an optimum established under the effect of some constraint. The concept can be understood only if it is seen in the process of urban transition. We thus designate the universal transformation that accompanies the move from an agricultural economy, exploiting mainly local resources, to an industrial and tertiary economy, founded on long-range exchanges. In countries with ancient settlement systems, like European or Asian countries, the same sites, the same population nodes, have been re-used by the economic and political systems ruling successively over the territories. The complete creation of new settlement sites, of new towns, is a very marginal process compare to the crushing majority of processes adapting already inhabited places to new functions. Settlement system were initially composed of villages, of small dimensio and little contrast, close to each other and relatively homogenously dispersed within the territory. They became more dense, and their average size increased due to demographic growth. But, above all, they modified the structure: the population became more concentrated, the 
FLUX n²1 July-September 1995

differences in size between the various elements of the system increased considerably. However, even though the smallest elements of the system are of greatly dimi-
nished importance, due to the absolute loss of population during rural exodus (generally the case for villages), or due to relatively slower growth (generally the case for small towns), these inhabited places still exist, in the small towns), these inhabited places still exist, in the ments belonging to the former settlement systems.

The spatial structure of these settlement systems, as well as their degree of hierarchization, today still depends on the modalities of circulation that were in application at the time they were set up. Thus, the average distance between towns and the intensity of the size contrasts over the national territory does not divide countries into developed vs. third world countries, but rather into countries of the old world and more recently populated countries (Moriconi, 1993). By way of example, the average distancing between two towns of more than 10,000 inhabitants is, in China or Europe, less than $15 \mathrm{~km}$, whereas in Noth America it is almost 50 $\mathrm{km}$. An index that measures the importance of hierarchical contrasts between the populations of these towns less than 1 in Europe and more than 1,2 in North Amerca. In all these systems, however, one notices over the long term a trend of accentuation of hierarchica contrasts, which can be explained, on the one hand, by the advantages gained by large towns from the hierarchcal dissemination of innovations (reinforcement of the hierarchy from the top down) and, on the other hand, by the contraction of space-time, which allows bigger towns to short-circuit the clientele of the smaller town in an intermediate position, inducing a "simplification" from the bottom up of urban hierarchy.

The gradual building of an increasingly hierarchical settlement system with increasingly marked contras between the size of its elements, is therefore a consequence, not of the optimal organization of circulation within a territory at a given moment (which condemns all static explanatory theories like those of central places or spatial economic balance), but of the gradual, historical adaptation of a system initially built in accordance with a certain circulation speed, that has transformed itself to allow faster speeds. In doing so, the system has also allowed societies to gradually free themselves from local ecological dependence with regard to the resources offered by their site, and it has also made it possible to reduce the risks and uncertainties threatening their survival and development, by considerably broadening possibilities of resource substitution and complementarity calling on the resources of increasingly distant sites.

\section{THE “OPERATORS” OF
SETTLEMENT SYSTEMS}

How has this essential finality been accomplished? Is it possible to identify operators who guide the evolution of settlement systems, or pilots or regulators of urban networks? In fact, when the concept of town networks was created by institutions that had the power to implement it, the representation requested from the system was always very partial, mainly military or administrative, and it is likely that the actions had hardly any decisive overall effect on the structure of the system. Usually, evolution occured "spontaneously", which leads us to view settlement systems as belonging to the "self-organizing" category of systems.

\section{CONSCIOUS OPERATORS}

Among the institutions that may have been able to conceive networks of centers and intervene directly in their implementation, those responsible for the defence of the territory come first (Pumain, Robic, 1995). The building of a network of strongholds on the borders of the territory happened in France as early as the seventeenth century, under the impetus of Vauban. It was theorized as a system of military sites organized to protect the entire national territory at the start of the eighteenth century by De Cormontaigne (Guillerme, 1987). However, while defensive concerns arose at various times during the history of site management of many towns, the military function alone has never led to the complete organization of the urban network of vast territories, apart from some particular colonized areas. In most settlement sys tems, it still only appears today in the functions of handful of specialized towns.

Political and administrative powers have doubtless had a more determining influence in the long term on the had a more determining influence in the long term on the organization of urban networks, whose regularity they continue to reinforce. The principle of non-coverage of teritorial administrative subdivisions, the efforts to obtain good accessibility for administrative centers, tend, indeed, to a regular spacing or centro of the sans, covel, each one being placed in the this is as toue for

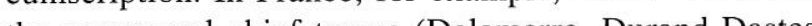
1984), as it is for the prefectures (Ozouf-Mrignier, 1984), as it is for the prefectures (Ozouf-Marignier, center, however, only rarely plays a totally selective role among all the towns existing at a given moment: the places were very often chosen because they occupied very good positions in the network for other attributes related to centrality.

It is certain, however, that, by means of the permanence that it often supposes and all the induced actions it nence that it often supposes and all the induced actions it leads to, the administrative function is a factor of

The differences in urban organization between centralized countries, where the importance of the capital tralized countries, where the importance of the capital
city is often excessive with regard to the rest of the syscity is often excessive with regard to the rest of the systhere is far less difference in the importance of towns at there is far less difference in the importance of towns at
the top of the hierarchy, directly reflect the presence of a the top of the hierarchy, directly reflect the presence of a politico-administrative operator in the organization of
settlement systems. Statistical proof is provided by a settlement systems. Statistical proof is provided by a
systematic comparison of the form of urban hierarchies in more than a hundred countries worldwide (Moriconi, 1993). However, this survey also shows that, in order to manifest itself, the effect of the politico-administrative manifest itself, the effect of the politico-administrative
operator requires duration. It is therefore not so much the political organization of the territory itself as all of the induced effects it engenders and which accumulate in the long term, that help to structure the settlement system. The entire apparatus of the states is moving in this direction.

The defensive and administrative functions tend to cover the territory with a regular grid of strongholds or tax collection centers and re-distribution of decision coming down from the top. Just like the military or politicians, tradesmen can also organize themselves with view to covering a territory with a network of outlets or branches. However, it is very rare that the operators in question benefitted at the outset from such wide organizational powers as the two previously mentioned types of actors. Despite the current logic of distribution, of the hierarchical organization of certain services offered to the population by large businesses, it is clear that the operative process of trade activity on setten obeys a different logic from that defined by the field o activity of a network operator. The coverage of a territory by networks of central places results from loca micro-competition and not from some central command.

After the function of territory coverage - recognized very early on and assigned to the population systen came an explicit, parallel function of landmarking itineraries which turned the urban centers into stages, or regularly spaced points on a course at the rhythm of travel in a given epoch. This function does not exclud the first because according to Mandeville, for example (1346, quoted by Deluz, 1989), this was the structure that had been adopted by the Gran Khan to govern his towards the linear organization of the territories of large countries, which wanted to find the means to link the center to the periphery as rapidly as possible in order to transmit information from the center to the frontiers, even if the rest of the territory remained under weak control. Urban network development theories, such as those of Kohl (1941) or Mackinder (1900), as old as those that fomulate the idea of territory coverage by towns, highlight the role of transport in the spatial organization of the settlement system (Pumain, Robic, 1995)

The manifest role of the interaction between the formation of settlement systems and that of circulation networks does not mean it is possible to express the settlement system as a "network of networks". This concep could explain the functioning at a given time, but it is neither explanatory nor genetic, as it is the settlement system itself which, once constituted, determines the location of all of the nodes and paths of the networks set up subsequently.

SELF-ORGANIZATION

Whatever may have been, or may still be, the efficiency of the actions explicitly aimed at controlling erritory by means of a regular distribution of centra functions, usually hierarchical, it can be taken as certain that they do not constitute the main determining factor in the structure and evolution of settlement systems. Intentional organizations would necessarily translate into greater variety of forms, depending on the political regime and the economic system, and by more pronounced surges in their evolution.

The majority of decisions that are taken and whose effect is to act upon the structure of the settlement system - individual decisions to migrate, decisions to set up a company, to construct buildings - are taken outside any authority planning or concerted intention, and most often in total unawareness of the existence of a "system" materializing the interdependencies between places of settlement. Even in the most policed states, there is no authority whose role it is to maintain the proportion observed in the evolution of settlement systems. It is in spite of the diversity of the personalities of the actors, 
of their behaviors produces regularities, as identifiable in the development of a town as in that of the settlement system. In reality, these "microscopic" actions are carried out under a strong constraint: the individual and collective actors that make up the social milieu of a tow are not independent, but connected, mutually informed of each others' actions, and they are in competition with actors of other towns to reap the profits linked to the exploitation of innovations. The roads and relationship that unite the towns in a given system are also social networks via which information transits. One town could not evolve independently of other towns, without its assets being either contested or copied. Competition between local actors in towns, which is the corollary to the relatedness of urban networks, leads to competition between the towns of a settlement system and explains the meta-stability of the system evolving under this constraint.

The structure of differentiation of the elements of the settlement system is maintained by the multiplicity of the interactions between the actors that make up each element. Everything happens as if, whereas social networks are renewed by the migration of people and from one generation to the next, some urban know-how wa perpetuated in the same places, which can only be understood by a series of feedback effects an constraints exerted by the places on the actors, and by learning processes demanding a fair amount of time before bringing significant results in urban competition.

This form of evolution recalls the phenomena of structuring already studied in various physical or living systems, and known under several names according to the origin: dissipative structures (Prigogine), or synergetic structures (Haken) (Pumain, Sanders, Saint-Julien, 1989, Sanders, 1992). The self-organization of settlement systems allows some analogies with the dynamic of open hierarchical systems, maintained under energy supply, likely to undergo bifurcations (Wilson, 1981), to quantitatively modify their structure and evolution under the effects of amplification of internal or external disturbances. In the history of settlement systems, an externa disturbance could be an event like the great plague of the fourteenth century in Europe, which hardly modified the system at all despite the fact that it reduced the population by half. The industrial revolution locally or regionally transformed the system by the emergence of new generation of towns. Local flucuations are of many kinds, like the decision to establish a capital, or the appearance of an innovation in a given place. Many have few develop sufficient stro pro of the systen, and only a
Town systems are, however, open systems of a particular kind. The territorial framework in which each town functions (all the places with with it has most relations, for a given type of exchange), is of variable openness is more important for the larger towns of each system, and the long term accumulation of the product of these long range interactions explains the very general overdevelopment (in size) of these metropolitan are compared to urban hierarchies of which they are the head (Jefferson, 1939, Moriconi, 1993). This remark underlines the fact that despite the many formal analogies between the settlement system and the dynamics of physical systems, and the value of model transfer for simulations (Allen, Sanglier, 1979, White, 1977), every precaution must be taken to make explict in models the specific nature of the settlement system.

Another important difference with physical system is linked to the cognitive dimension. The informatio is archical form and specializations) is at least partially known to the actors, who can either conform to it or contest it. This reflexive aspect, including the representation of the system, even partial, in its development, quite clearly differentiates the settlement system from ther self-organizing systems like some physical sysems. This justifies the search for a specific, evolutive heory for these systems (Pumain, 1995) and the fact that some players are tempted to act directly on settlement systems.

\section{IS INTERVENTION DESIRABLE?}

In developed countries where urban transition is inished, where almost the entire population lives in towns, the dissemination of urbanization seems to have teached its final stage, of so-called saturation. On might think that the former modalities of evolution of settlement systems would be likely to change. Some people thus tried to interpret the reversal of migration trends between towns and the countryside during the 60 and 70s in the USA and at the end of the 70s and 80s in Europe, as a major bifurcation, the start of a tren towards "counter-urbanization" (Berry, 1976). Subsequent evolution has shown this interpretation to be erroneous. The renewed growth of rural areas is explained on the one hand by the spreading of the outskirts of urban areas, a spatial extension brought about by the dissemination of automobiles and improved accessibility,
as well as by improved living standards allowing the acquisition of individual accommodation. In addition, the renewed growth of some villages or small towns at that time signified the end of a phase of dissemination of modernization linked to strong post-war economic and demographic growth down to the bottom of the hierarchy and in the furthest corners of the territory.

The forseeable evolution for current settlement systems is ded tems is dyn und the constraint of another com their past space-time. Modern techniques make it possible to considerably accerate the speed of inter-urbassible to nications, and this process continues to extend its effects to an increasing number of towns (globalization). The only limitation to this process is the finite nature of the world, but the world's town system is still far from being connected to the available reserve of speed. The being connected to the available reserve of speed. The ture of settlement systems are a reinforcement of their hierarchical structure, which starts at the top, the identified phenomenon since the end of the 1980 s being "metropolization". There is nothing new about this phenomenon, it is merely the translation in the town system of their adaptation to a new cycle of innovations, numerous technical, social and cultural novelties accompanying the progress in speed of communications. The effects of this cycle will be disseminated hierarchically in the settlement system. The more the dissemination of metropolization is delayed in time and is spatially selective, the more it will contribute to the reinforcement of urban hierarchies.

Intervening in a self-organizing process is not easy. The local reactions of towns threatened by the effects of metropolization, whether it concerns the setting up of technical poles, of urban marketing or participation in local or European networks, have been very quickly copied and generalized to most of the towns in the system. The normal modality of evolution of these entities which constitute the population nodes is still competition and rivalry for the capturing of resources, and this is the case from quarrels between villages through rivalries between large towns for the acquisition of infrastructures.

The power of self-organization mechanisms is proved, on the contrary, by the difficultes experienced by governments, concerned with modifying urban organizations that seem to be incompatible with objectives of territorial equity, or that are trying to achieve improved economic efficiency or improved performance when faced with international competition. It is unnecessary to become weighed down on this subject about the uncertain effects of policies aimed at reducing the weight of the
Paris urban area, a typical example of a "primatial" town in a developed country. Similarly, at the other extreme of the urban hierarchy, one cannot be sure of predicting the success of DATAR's "towns network", destined to disactivate the economically disastrous effects of still lively local competition between medium-sized close town which could be united in the same life basin.

Must we resign ourselves to accepting the unavoidable evolution of our town systems toward concentration in bigger and bigger, more and more sprawling metropolitan cities? Must we accept that the construction of the European Union will eventually mean the formation of a megalopolitan entity of some fifteen or twenty million inhabitants at the head of European urban network? Knowledge of the modalitie of the evolution of settlement systems does not imply resignation; it underlines the extent and force of interresignation; it underlines the extent and force of inter-
vention necessary to alter their course. Thus, if Europeans intend to preserve the heritage that small an medium-sized towns represent, and whose great numbe and high density characterize the settlement system, they must be prepared to implement interventionist policie which are strong, costly (at least according to curren accountancy norms, which hardly evaluate harmful or positive effects on living conditions) and long-lasting.

\section{CONCLUSION}

The settlement system in a territory can be compared ense that it fulfills the functions of control, service and capillary irrigation of territory, by articulating the two main levels of relationa life: that which constitutes the territory of daily life, an that which forms political, cultural or economic territories. However, a functional interpretation of these systems cannot be limited to this static perspective, insofa as settlement systems evolve by constantly adapting the spatial structure or territories to the constraint of reducing the uncertainties of the immediate environment; thi is the permanent objective of human societies.

Through the settlement system come both the invention of technical, social and cultural novelty, as well a the resolution of the risk of unbalance thereby created, thanks to the organization of the dissemination of these novelties. It is through the settlement system that most innovations and access to modernity are made available to the majority. The settlement system differs, however, from the great technical systems because it is self-organizing. In spite of very partial interventions, its structure 
FLUX

$n^{\circ} 21$

July - September
1995

pp. $21-36$
The automobile system: a territorial adapter concerted decisions, and so far seem to have escaped all ttempts on the part of the operators to control them. It is the competition between the actors linked to place that produces the main structural regularities and the foration of differes the very strong the diftusion of innovaton, while the very strong connexily of the system contributes to stabilizing its own evolution. The imporplexity of the levels of town a the alapaility of the pystem liken it more to living systems than to self- organizing physical systems, whereas the reflexive an

With the mastery of large technical systems the tempation may grow stronger to govern the system. Initially envisaged within each element, on a communal, then metropolitan scale, will control over development reach the setlement system, by an appropriate technicalization of the concept of the system? The definition of relevant interventional of the sy will ho doubt have to wait for inproved knowledge and more ela
ALLen P., SANGLier M. "A dynamic model of growth in a central place system." Geographical Analysis, 11, 1979, pp. 256-272.

BRUNET R. "Le déchiffrement du monde." In Mondes ouveaux, vol. 1., R. BRUnet, o. Dollfus, eds. Paris: Hachette-RECLUS, "Géographie Universelle," 1990.

CARROLL. "Types of city-size distributions, a comparative analysis." In Urbanization history. Ed. VAN DER WOUDE A.D., DE VRIES J., HAYAMI A. Oxford: Clarendon Pr., 1990.

CHRISTALLER W. Die zentralen Orte in Suddeutschland. Iena: Fischer, 1933

Delamare A Durand-Dastes “Le maillage communal." Géoscopie de la France. Ed. T. Quant Paris: Minord, 1984, pp. 119-152.

Deluz C. "Villes et organization de l'espace : la Chine de Marco Polo." In Villes, Bonnes villes cités et capitales. Mélanges offerts à Bernard Chevalier. Tours: 1989.

FLETSCHER R. "Settlement in archaeology: a world-wide com parison." World Archaeology, 18, 1, 1986, pp. 59-83.

FRANKHAUSER P. La fractalité des structures urbaines. Paris Anthropos, 1993

GUILLERME, A. L'émergence du concept de réseau. Group Réseaux, cahier $\mathrm{n}^{\circ} 5.1987$

HAGGETT P., CHORLEY R.J. Network Analysis in Geography. London; Edward Arnold, 1969.

HUBERT J.P. La discontinuité critique. Paris: Publ. de la Sorbonne, 1993.

JEFFERSON. "The law of primate city." Geographical Review, 29, 1939, pp. 226-232.

KонL. Der Verkehr und die Ansiedlungen der Menschen in inrer Abhängigkeit der Gestaltung der Erdoberfläche. Dresden/Leipzig: Arnold, 184

MACKINDER H. "The physical basis of political geography." Scottish Geographical Magazine, VI, 1900, pp. 78-84.

MoRICONI F. L'urbanisation du monde depuis 1950. Paris: Anthropos, 1993.
Ozouf-Marignier M.V. La formation des départments. La représentation du territoire français à la fin du XVIIIe représentation du territoive
siècle. Paris: EHESS, 1992.

Pinchemel P., Pinchemel G. La face de la terre. Paris: A. Colin, 1988

PRED A. City systems in advanced societies. London: Hutchison, 1977.

Pumain D. "Les systèmes de villes." In Encyclopédie de géographie. Ed. A. BAilly, R. FerRAs, D. Pumain. Paris: Economica, 1992, pp. 645-663.

PUMAIN D. "L'espace, le temps et la matérialité des villes." In Temporalités urbaines. Eds. B. LePETIT, D. PUMAIN. Paris: Anthropos, coll. Villes, 1993.

PUMAIN D. "Vers une théorie évolutive des villes." L'Espace

PUMAIN D., RoBic M.C. "Théoriser la ville," In Penser et repre senter la ville. Eds. P.H. DERYCKE JM. HURIOT. D. PUMAN. Paris: Anthropos (forthcoming).

PUMAIN D., SANDERS L, SAINT-IULIEN, T. Villes et auto-organization. Paris: Economica, 1989

PUMAIN D., SaINT-JuLIFN T. Les dimensions du changement urbain. Paris: CNRS, 1978

REYMond н. "Une problématique théorique." In Problématiques de la géographie. Eds. H. ISNARD, J.B. RACINE, H. REYMOND. Paris: PUF, 1981, pp. 163-262.

RoBIC M.C. "Cent ans avant Christaller, une théorie des lieux centraux." L'Espace Géographique, 1, 1982.

SANDERS L. Systèmes de villes et synergétique. Paris: Anthropos, coll. Villes, 1992

DE VRIES J. European Urbanization, 1500-1800. London: Methuen, 1984.

WHITE R. "Dynamic central place theory: results of a simulation approach." Geographical Analysis, 10, 1977, pp. 201-

WILSON A. Catastrophe theory and bifurcation. London, Croom Helm, 1981
Gabriel DUPUY is Professor at the University Paris X-Nanterre and at the Ecole Nationale des Ponts et in the fields of territorial developmen and planning, transportation and, more generally, networks and communications systems. He has and abroad, particularly on the topic of the "urbanism of networks". Two of his most recent publications include Les Economica, 1995) and L'auto et la ville (Flammarion, 1995). He is currently Director of the Interdisciplinary Program of Research $I_{\text {this }}$ is an assortment of more or less sophisticated electrical plugs of various sizes, with transformers for different types of current; sometimes there are AC/DC transformers or rectifiers. This device makes it possible to obtain electricity for any type of appliance, from any network supplying electrical current of any kind. The apparatus is small and lightweight and forms part of the necessary travel equipment for the experienced international traveller, as many different national electrical standards still exist (David and Bunn, 1991). How else could one use a portable computer, electric razor, or electrical travel iron on a trip abroad, when neither the wattage, tension, or the shape of the plug correspond to what is found at home? The universa adapter is long-term insurance for the traveller, a general guarantee that under any circumstances he will have access to the indispensable element which electricity has become, a "comfort zone" whose bound
the possibility of being able to plug into the network.

In this paper (which borrows from two recent works by the author; see Dupuy 1995a, 1995b), we shall demonstrate that the automobile plays an identical role of universal adapter in the service of the "travellers" we have become in a world undergoing enormous transformations. This is not to say that we are permanent globe-trotters. Rather, the multiple changes being produced in human society as a result of economic and social evolutions, would cause us to lose control of the space around us, lessening our potential for territorial appropriation,were we not a larger and larger group to own cars, which have truly becone a type of universal teritorial adapter. It is this rol which explains, in my opinion, the incredible development of the automobile throughout the world

We shall begin by tracing the history of the phenomenal growth of the automobile, recalling here for the record the dire forecasts of the 1970s that predicted quite another story. We shall then demonstrate how the automobile has found a place today in a comprehensive, more and more fully integrate system. The question here arises concerning the public-private mixed economics of this system, which for many has conferred absolute advantages on the automobile in terms of ensuring long-term territorial dominion. We shall closely examine two historic examples of the role of adapter played by the automobile: American suburbanization, and French rural urbanization, or "rurbanization". Other exanples will show the extent to which the utomobile is likely to play out its technical role of territorial adapter, thus 